\title{
Do silver nanoparticles stimulate the formation of ectomycorrhizae in seedlings of pedunculate oak (Quercus robur L.)?
}

\author{
Marta Aleksandrowicz-Trzcińska ${ }^{1}$ (D) Jacek Olchowik ${ }^{1,2} \cdot$ Marcin Studnicki $^{3} \cdot$ Alexander Urban $^{4}$
}

Received: 9 July 2018 / Accepted: 14 May 2019 / Published online: 1 June 2019

(C) The Author(s) 2019

\begin{abstract}
Metal nanoparticles are gaining ever-wider application in agriculture and forestry, as alternatives to chemical agents used as fertilisers, growth stimulators and pesticides, establishing a need for eco-toxicological risk assessment of these agents. We tested the effects of foliar-applied silver nanoparticles (AgNPs) on chlorophyll a fluorescence and on abundance and species composition of ectomycorrhizal (ECM) colonisation. The application of AgNPs at concentrations of 5,25 and 50 ppm was found to stimulate the formation of mycorrhizae in seedlings of pedunculate oak, with the highest effect at intermediate concentrations $(25 \mathrm{ppm})$. There were non-linear effects on the relative abundance of ECM fungal species. The proportion of dominant T. terrestris was highest in the control group, whereas the shares of ECM formed by the two other species, S. brunnea and P. involutus, were higher in the treatments with intermediate and maximal concentrations of AgNPs, respectively. Maximum quantum yield of photosystem II ( Fv/fm) assessed by chlorophyll $a$ fluorescence measurements revealed slight debilitation of oak seedlings irrespective of the application of AgNPs and their concentrations. This result offered an indirect indication that photosynthesis capacity had no influence on the level of mycorrhization. We hypothesise that foliar AgNPs treatments at concentrations below thresholds of acute toxicity and in the absence of significant effects on chlorophyll a fluorescence may still exert significant influence on biotic interactions including mycorrhizal symbioses by impacting plant hormonal balance, particularly ethylene, and regulatory pathways involved in host control of ECM colonisation.
\end{abstract}

Keywords Chlorophyll fluorescence $\cdot$ Paxillus involutus $\cdot$ Thelephora terrestris $\cdot$ Sphaerosporella brunnea

\section{Introduction}

Nanoparticles (NPs) are atomic or molecular aggregates with two dimensions between 1 and $100 \mathrm{~nm}$ (Klaine et al. 2008). It

Marta Aleksandrowicz-Trzcińska

marta_aleksandrowicz_trzcinska@sggw.pl

1 Department of Forest Protection and Ecology, Faculty of Forestry, Warsaw University of Life Sciences, Nowoursynowska 159, 02-776 Warsaw, Poland

2 Department of Plant Pathology, Faculty of Horticulture, Biotechnology and Landscape Architecture, Warsaw University of Life Sciences, Nowoursynowska 159, 02-776 Warsaw, Poland

3 Department of Experimental Design and Bioinformatics, Faculty of Agriculture and Biology, Warsaw University of Life Sciences, Nowoursynowska 159, 02-776 Warsaw, Poland

4 Department of Botany and Biodiversity Research, Faculty of Life Sciences, University of Vienna, Rennweg 14, A-1030 Wien, Austria is the combination of such small dimensions and the proportionately large external surface area that is known to confer physico-chemical and bioactive properties on nanoparticles that are markedly different from those characterising bulk material of the same kind ( $\mathrm{Nel}$ et al. 2006). NPs have a wide range of potential applications in agriculture and forestry, inter alia as alternatives to the chemicals used as fertilisers, growth stimulators and plant protection agents (Abd-Elsalam 2012; Mukhopadhyay 2014). Furthermore, NPs are increasingly used in various industries and consumer products, resulting in the release of synthetic NPs into the environment and causing increasing eco-toxicological concern (Sweet and Singleton 2015).

Research to date points to a differentiated influence of nanoparticles on higher plants, in that both positive and negative effects have been noted (Rizwan et al. 2017). Such differences relate i.a. to species of plant, growth conditions (e.g. in soil or different nutrient media), type and concentration of nanoparticles, means of application (foliar or soil) and dose applied (Ruffini Castiglione and Cremoni 2009; Ma et al. 2010; Arruda et al. 2015; Rizwan et al. 2017), This all ensures 
considerable difficulties with any comparing of obtained results (Sweet and Singleton 2015). However, many authors point to a positive influence of nanoparticles on seed-germination, plant growth, chlorophyll content and the course assumed by photosynthesis (Zheng et al. 2008; Sharma et al. 2012; Syu et al. 2014; Razzaq et al. 2016).

Mycorrhizal symbiosis is of key interest to foresters, because the fungi responsible influence the productivity of trees and diversity of stands, playing a key role in the cycling of carbon, nitrogen and phosphorus (van der Heijden et al. 2015). Mycorrhizal development and functioning is shown to be under the marked influence of environmental factors, host plant, the physiology of the symbiotic fungi, and interactions with other soil microorganisms (Smith and Read 2008). Equally, the deployment of nanoparticles (as growth stimulators or plant protection agents) in the nursery production of seedling trees for forestry is linked with certain dangers that influences on both host plant and mycorrhizal partner will prove unfavourable.

Currently, there remains little research on the influence nanoparticles exert on the state and structure of mycorrhizal fungi. Most of the work that has been done concerns arbuscular mycorrhiza, with results resembling those concerning the influence on plants, in that there is ambiguity. While some studies point to a negative influence of nanoparticles on the mycorrhizal colonisation of plant roots (Dubchak et al. 2010), others suggest that, at low concentration, there is no discernible impact on levels of mycorrhizal colonization, even if high concentrations do indeed seem to curb this (Judy et al. 2015; Cao et al. 2017). For their part, Feng et al. (2013) reported a stimulatory influence of AgNPs on the formation of arbuscular mycorrhizae irrespective of concentrations investigated.

Contradictory results have been supplied by different authors researching effects of AgNPs on ECM symbiosis. Sweet and Singleton (2015) showed how soil contamination with high doses of AgNPs contributed to a drastic reduction in the diversity of ectomycorrhizal fungi on the roots of seedling bishop pines (Pinus muricata); while Olchowik et al. (2017) found different influences of foliar-applied metal nanoparticles on the formation of ectomycorrhizae of pedunculate oak seedlings, in relation to both type of particle and concentration. While the influence of AgNPs was stimulatory at all tested concentrations, that of copper nanoparticles was shown to be positive at low concentrations, inhibitory at higher ones.

Among the methods by which the impacts on plants of both biotic and abiotic stress factors are researched, it is chlorophyll $a$ fluorescence measurement in vivo that has gained wide application (Maxwell and Johnson 2000). Interactions between AgNPs, photosynthesis and chlorophyll a fluorescence may involve diverse mechanisms. Chlorophyll fluorescence quenching by AgNPs was demonstrated in vitro (Falco et al. 2015). In vivo the disruption of energy transport is the main mechanism inhibiting maximum and effective quantum yield of PS II, inhibiting the photo-protective capacity of PS II and resulting in the induction of reactive oxygen species in the chloroplast, in inhibition of Rubisco and in decreased $\mathrm{CO} 2$ assimilation (Jiang et al. 2017). AgNP impact on on PS II is a key mechanism of AgNP toxicity to plants, therefore chlorophyll a fluorescence measurements appear to be particularly suited the assess this impact. However, most studies on AgNPs, photosynthesis and chlorophyll a fluorescence used algae or aquatic plants (e.g. Jiang et al. 2017). The more complex and resistant structures of land plants foliage constitute barriers to protect the chloroplasts from environmental stressors, reducing the impact of AgNPs on photosynthesis, too. Furthermore, plants challenged with AgNPs can increase chlorophyll content, potentially overcompensating inhibitory effects on photosynthesis, as demonstrated in Brassica juncea (Sharma et al. 2012).

The objectives of the work detailed here were: (1) to assess plant condition on the basis of chlorophyll $a$ fluorescence measurements following AgNPs application, (2) to compare the abundance of mycorrhizal fungi on seedlings of pedunculate oak in relation to applications of AgNPs at different concentrations.

\section{Materials and methods}

\subsection{Study design and plant material}

The study was conducted at the nursery of the Forest Experimental Station of Warsaw University of Life Sciences (at Rogów, $51^{\circ} 40^{\prime} \mathrm{N}, 19^{\circ} 55^{\prime} \mathrm{E}, 195 \mathrm{~m}$ a.s.l). Seedlings of pedunculate oak were grown in V-360 plastic container trays (15 pots per tray with a capacity of $360 \mathrm{~cm}^{3}$ ) in a peat-perlite substrate purchased from the container nursery at Nędza, Rudy Raciborskie Forest District, Poland. The substrate $(\mathrm{pH}=4.5)$ comprised sphagnum peat from Estonia - 85\%, plus coarse-grained perlite (No. 3) - 15\%, the latter being thought to improve the aeration of the substrate. Seedlings were fertilised with a mixture of Osmocote Exact Standard controlled-release fertiliser with differential release characteristics: 3-4 M, 5-6 M, 8-9 M (1:1:1). The seeds of pedunculate oak were of local origin, from managed forest. On May 12th 2015, two oak acorns respectively were seeded to each pot, in order to obtain seedlings in each. After germination, one plant per pot was selected at random, while the others were removed. Colonization by ECM fungi occurred spontaneously. There were four spray treatments of the seedlings' aerial parts using $1000 \mathrm{l} / \mathrm{ha}\left(=100 \mathrm{ml} / \mathrm{m}^{2}\right)$ aqueous solutions of AgNPs at concentrations of $0,5,25$ and $50 \mathrm{ppm}$. Previously, the NPs had been suspended in deionised water by way of vigorous shaking for at least $10 \mathrm{~min}$. Nanoparticles were applied to foliage four times, i.e. on 11 and 25 June, 9 July and 6 August 2014. The first treatment was applied one month after sowing, by which time the seedlings had formed two leaves. 
Sprayings were done in the early morning, with a manual compressed air sprayer (Kisan Kraft, model KK-PS5000).

The experiment was performed on a randomised complete block design. At the end of the growing season (October), 40 seedlings ( 10 plants $\times 4$ blocs) were harvested at random from each treatment, 160 seedlings sampled in all.

\subsection{Nanoparticles}

Samples of commercially available solutions of AgNPs were purchased from Nano-Koloid (Nano Koloid Sp. z o. o), as a licensee of Nano Technologies Group, Inc. (USA), manufactured in accordance with European patent EP2081672 A2. As the producer notes, these are generated by way of a physical process, consist of around 100 atoms each, and are suspended in demineralised water. The concentration of nanoparticles in the commercially-available product is $50 \mathrm{ppm}$.

\subsection{Chlorophyll $a$ fluorescence measurements}

The fluorescence measurements for chlorophyll $a$ were made using a Hansatech FMS-2 fluorimeter (Hansatech Ltd., Kings Lynn, UK), on 1, 10, 17, 24 and 31 July; 7, 14, 21 and 28 August; and 15 and 28 September 2015. They were performed on 10 randomly-selected, fully-developed leaves from 10 oaks in the case of each treatment variant. With the aid of clips, leaves were first adapted to darkness for a period of $20 \mathrm{~min}$ before being connected up to an optical fibre. The fluorescence parameters considered in relation to chlorophyll $a$ were: Fo - i.e. initial (zero) fluorescence following adaptation to the darkness, Fm maximum fluorescence following adaptation to the darkness, and $\mathrm{Fv} / \mathrm{fm}$ - as the maximum efficiency of photosystem II (PSII), where $\mathrm{Fv}$ - is the fluorescence variable Fm-Fo.

\subsection{Assessment of ectomycorrhizae}

The roots of harvested seedlings were analysed under a stereoscopic microscope (Delta IPOS-808), as coupled with a digital camera, at 10-40× magnification. The degree of mycorrhization was determined by classifying and counting mycorrhizal and non-mycorrhizal root tips. The proportion of mycorrhizal root tips was calculated as: (mycorrhizal root tips) / (mycorrhizal root tips + non-mycorrhizal root tips) $\times 100$, and presented as degree of mycorrhization. The abundance of individual ectomycorrhizal fungal taxa was calculated as the number of ectomycorrhizal root tips of each morphotypes divided by the total number of roots tips and multiply by 100 . The frequency of ectomycorrhizal taxa was expressed as the percentage of colonized plants. Ectomycorrhizal tips were identified under a dissecting microscope by the absence of root hairs, shape (hypertrophy) and colour of fine roots, as well as the presence of mycelial mantles and emanating fungal structures (hyphae and rhizomorphs). The initial identification of morphotypes was based on the literature (Agerer 19872008). Representative mycorrhizal root tips of each morphotype were photographed and deposited in an internal database, together with fungal descriptions and molecular information. To determine mycorrhizal species, we collected tip material from three to five mycorrhizal root tips per morphotype, and transferred them into eppendorf tubes filled with $70 \% \mathrm{EtOH}$ for molecular analysis.

Identification of mycorrhizal fungi included PCR amplification of selected regions of internal transcribed spacer (ITS) rDNA using the primer pair ITS1F / ITS4 (Gardes and Bruns 1993; White et al. 1990) and sequencing of the resulting PCR product. We used direct PCR amplification of fungal DNA from ECM samples, bypassing conventional DNA extraction procedures (Iotti and Zambonelli 2006). PCR products were assessed by loading $2 \mu \mathrm{L}$ on to a $1 \%$ agarose gel $(0.5 \times$ TAE buffer) and visualised under UV light, using the GeneRulerTM $1 \mathrm{~kb}$ Plus DNA Ladder (Fermentas). Bidirectional Dye-Terminator Cycle Sequencing was performed using BigDye Terminator v3.1 Chemistry (Applied Biosystems) and one of the PCR primers each. The resulting fragments were analysed on a 3730 DNA Analyser at the Department of Botany and Biodiversity Research of the University of Vienna. Identification of sequenced fungi was based on the results of BLAST (Altschul et al. 1997) searches against the National Centre for Biotechnology Information (NCBI) public database, with subsequent phylogenetic placement and queries to the UNITE database (Kõljalg et al. 2013).

\subsection{Statistical analysis}

Analysis of the effects of the different concentrations of AgNPs on the abundance of mycorrhizal fungi was performed using Generalised Linear Models (GLM) for a randomised complete block design with a binomial probability distribution. The Tukey test was used in pairwise comparisons (as a post hoc test) between different concentrations of AgNPs. We tested the significance of changes in fluorescence over time, with different concentrations of AgNPs applied, using a growth-curve model. The statistical analysis was performed using $\mathrm{R}$ version 3.3.3, with the accepted level of significance set at $p<0.05$.

\section{Results}

Mean values (for all measurement dates) for the maximal efficiency of photosystem II (given by $\mathrm{Fv} / \mathrm{fm}$ ) were found to range between 0.79 where no AgNPs were applied, and 0.76 - in the case of the treatment variant with $50 \mathrm{ppm}$ AgNPs applied (Fig. 1). They were not found to vary significantly in relation to either application of AgNPs and their concentrations, or time of measurement $(p=0.1693, p=0.1104$ respectively). 
Fig. 1 Chlorophyll $a$ fluorescence, i.e. maximal efficiency of photosystem II (Fv/ $\mathrm{fm}$ ) in oak seedlings treated with different concentrations of AgNPs. Points denote mean values established by reference to 10 measurements made on each of 11 different dates (where date $0=$ July 1 )

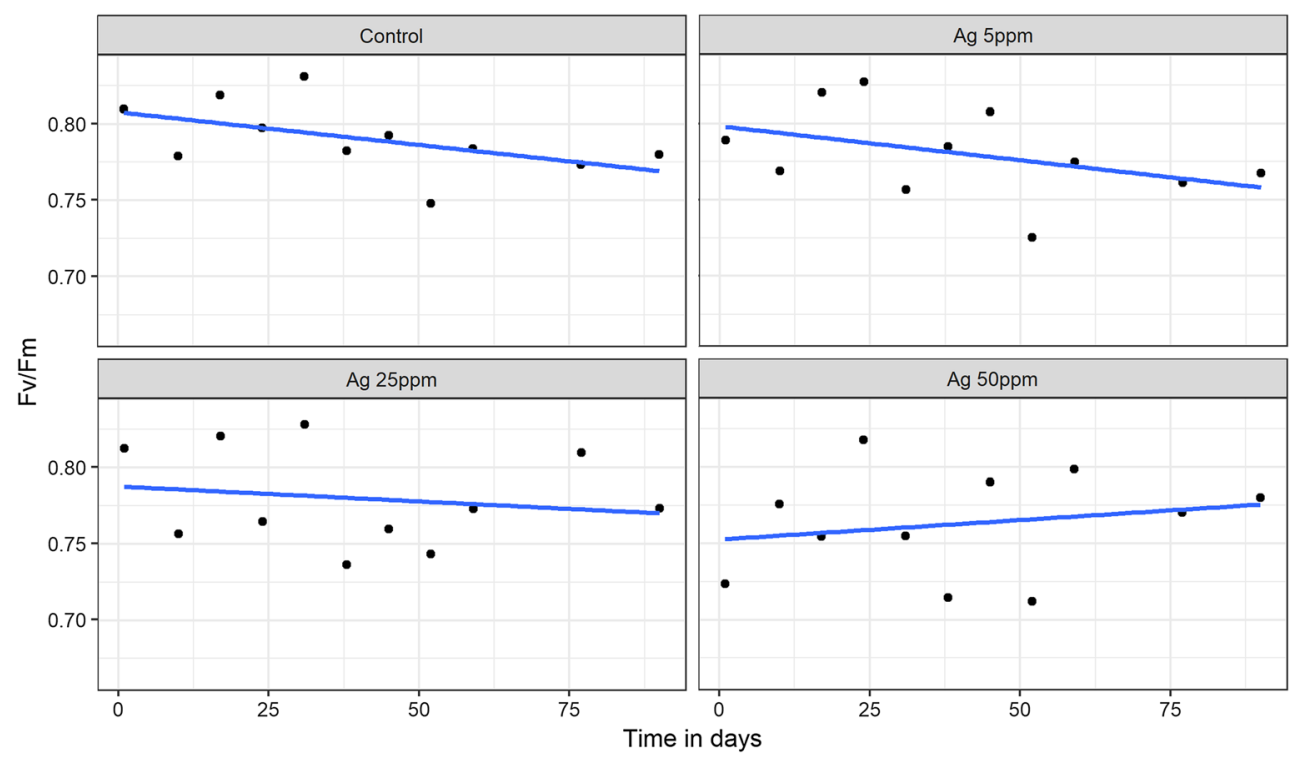

The mean proportion of short roots with vital mycorrhizae present in seedlings of pedunculate oak in all of the experimental treatments was $47.8 \%$. The use of AgNPs at all different concentrations was associated with a higher level of mycorrhizal colonisation than was present in the control $(42.5 \%$, $\mathrm{df}=3, p<0.00001)$. The highest level reported was the $54.2 \%$ associated with the application of AgNPs at a concentration of 25 ppm (Fig. 2).

The 3 fungal species identified were one representative of the Ascomycota (.i.e. Sphaerosporella brunnea, KC008076.1, identity 98\%), and two of the Basidiomycota (i.e. Thelephora terrestris, FJ809998.1, identity 99\% and Paxillus involutus EU078725.1, identity 98\%). T. terrestris was the most abundant ECM species in all treatments
(32.4\% on average), reaching highest levels under control conditions (35.1\%) and the lowest levels (27.9\%) in the $5 \mathrm{ppm}$ AgNP treatment. There were quite disparate shares of $S$. brunnea on the roots of the seedlings studied - only a third or half as many in the treatment receiving no application of AgNPs (at 4.5\%), as compared with the treatments actually receiving the nanoparticles. The largest share was the $16.1 \%$ noted where AgNPs had been applied at a concentration of $25 \mathrm{ppm}$. The proportion of $P$. involutus ECM was highest in the treatment with the highest dose $-50 \mathrm{ppm}$ of AgNPs (6.6\%), and lowest in the control treatment (3.1\%). 5.3\% were recorded in the $5 \mathrm{ppm}$ treatment, $3.4 \%$ in the $25 \%$ treatment (Fig. 2). The most frequently observed EMC fungus was $T$. terrestris (Table 1).

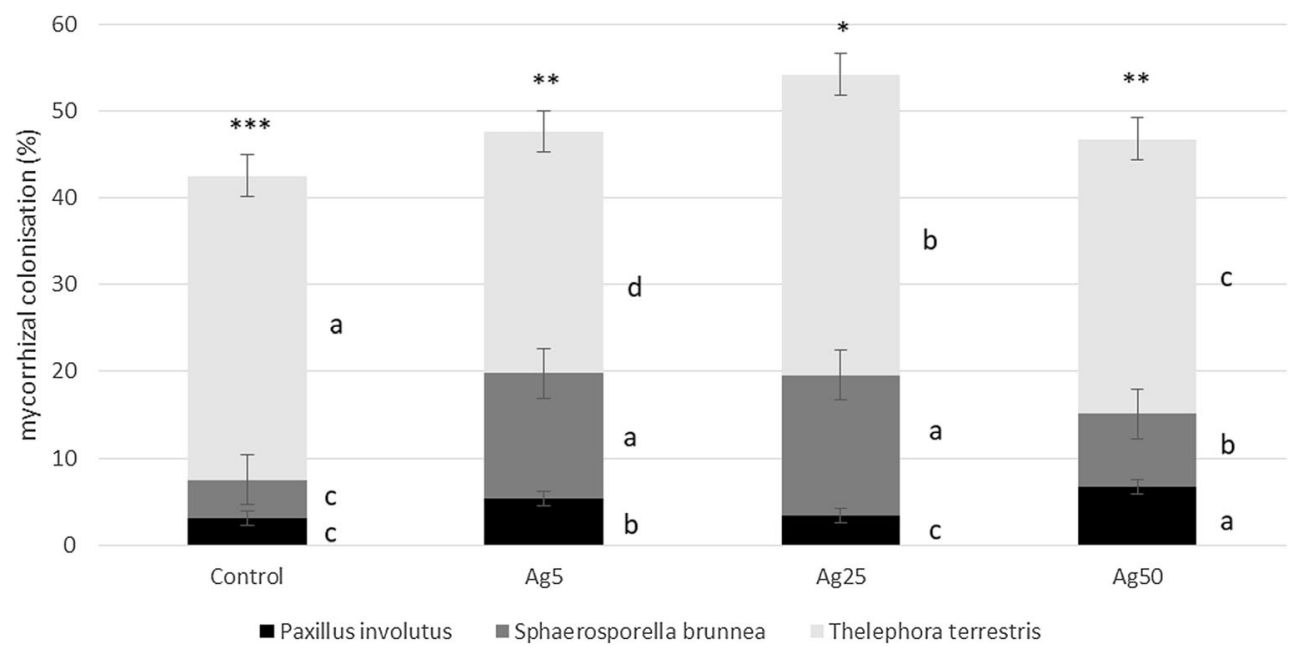

Fig. 2 Degree of mycorrhization and abundance of ECM fungi: Thelephora terrestris, Sphaerosporella brunnea and Paxillus involutus [\%] of oak roots treated with concentrations of AgNPs equal to 00 ppm; 5-5 ppm; 25-25 ppm; 50-50 ppm. Numbers of asterisks indicate significant differences between concentrations of AgNPs for degree of mycorrhization assessed with Tukey's test $(\alpha=0.05)$, different letters indicate significant differences between concentrations of AgNPs for each ECM taxa assessed with Tukey's test $(\alpha=0.05)$. While error bars represent standard error 


\section{Discussion}

$\mathrm{Fv} / \mathrm{fm}$ values between 0.78 and 0.85 are considered indicative of healthy, nonstressed deciduous trees, including $Q$. robur seedlings (Percival 2005). The mean Fv/fm values (all measurement dates averaged) observed, ranging between 0.76 and 0.79 , were distributed around the lower margin of the range of reference values for optimal growth conditions.

The absence of significant effects of foliar AgNP treatments on chlorophyll a fluorescence was unexpected, since this parameter is considered to be sensitive to various stressors, and since ultrastructural alterations of chloroplasts had been observed in a previous study under similar experimental conditions (Olchowik et al. 2017). On the other hand, this result is compatible with the lack of effects on the seedlings' growth parameters (Olchowik et al. 2017). While chlorophyll a fluorescence is not strictly proportional to the intensity of photosynthesis (expressed via the assimilation of $\mathrm{CO}_{2}$ or emission of $\mathrm{O}_{2}$; Maxwell and Johnson 2000) it seems unlikely that increased levels of mycorrhizal colonisation linked to AgNPs treatments (see below) were due to increased photosynthesis, which might have increased the amount of sugar reaching the roots and ECM fungi (Högberg et al. 2008).

The mean proportion of short roots with ectomycorrhizae present in seedlings in all of the experimental treatments was $47.8 \%$. The level of mycorrhizal colonisation is typically found to depend on several factors, such as cultivation system (bare-root vs. container, outdoor vs. greenhouse), plant species (Menkis et al. 2005) and the place or nursery in which the seedlings have been grown (Iwański et al. 2006). It is typical for seedlings grown outdoor, with bare-root systems, to be characterised by almost $100 \%$ mycorrhizal colonisation (Leski et al. 2010; Pietras et al. 2013), while the level of colonisation of seedlings grown up in peaty substrates in greenhouse is often lower than this (Menkis et al. 2005).

The use of foliar-applied AgNPs at all different concentrations was associated with a higher level of mycorrhizal colonisation than was present in the control. Similar stimulation of the formation of mycorrhizae was observed in our previous research, in which AgNPs were applied as an alternative to fungicides, with a view to powdery mildew of oak being combated (Olchowik et al. 2017). However, results different from ours were obtained by Sweet and Singleton (2015), in their work with the Bishop pine (Pinus muricata) exposed to soils treated with AgNPs. Intensified application of AgNPs was found to reduce, not only the level of mycorrhization, but also the biodiversity of ectomycorrhizal fungi at the level of the genus (from 5 to 1 ).

The 3 fungal species were identified: $T$. terrestris, $S$. brunnea and $P$. involutus. All of these are typical, commonly-occurring ECM partners of forest tree seedlings, be they produced in bare root or in containers nurseries (Menkis et al. 2005; Rudawska et al. 2006; Sánchez et al. 2014).

T. terrestris was the most abundant and frequent ECM species in all treatments (Table 1, Fig. 2). T. terrestris is a pioneer mycobiont, well adapted to nursery conditions (Iwański et al. 2006) or plantations, especially at sites that have been treeless, and thus symbiont-free, for many years (Last et al. 1987). Populations of $T$. terrestris which are not adapted to trace metal stress were found to be very sensitive to high concentrations of AgNPs, like other species of ECM fungi (Sweet and Singleton 2015). Furthermore, T. terrestris is considered only poorly competitive with other ectomycorrhizal fungi (Villeneuve et al. 1991). Maximal abundance was recorded in the control treatment, but the moderate decrease in AgNP treatments was not linearly related to AgNPs dose. Variation in the abundance of T. terrestris at different levels of AgNP treatments might be the result of competitive interactions with the other ECM fungal species present.

The share of $S$. brunnea was two-three times higher as a result of the application of nanoparticles. The pyrophilous ascomycete $S$. brunnea is a pioneer and opportunist ectomycorrhizal species, and the most common fungal competitor in nurseries producing plants mycorrhized with Tuber species, where it can reproduce abundantly, via ascomata and via conidiospores (Sánchez et al. 2014). In natural forest environments fruiting of $S$. brunnea is rarely observed and typically restricted to rather recent fireplaces, a more or less alcaline and chemically reactive substrate quite different from forest soils, which is colonised by highly specialised, stressresistant pioneer species. S. brunnea was also reported to occur in zinc mine spoils, in the presence of high concentration
Table 1 Frequency (percent of colonized plants \pm standard errors) of fungal taxa on roots of $Q$. robur seedlings treated with different concentrations of AgNPs. GenBank accession numbers of sequences (accession no), best match in GenBank, percent of identity between the best match and representative sequence of the taxa (identity). For each fungal EMC taxa, one sequence was deposited

\begin{tabular}{|c|c|c|c|c|c|c|c|}
\hline \multirow[t]{2}{*}{ ECM taxa } & \multirow[t]{2}{*}{ Reference sequence } & \multirow[t]{2}{*}{ Accession no } & \multirow[t]{2}{*}{ Identity $(\%)$} & \multicolumn{4}{|c|}{ Treatment $(n=40)$} \\
\hline & & & & Control & Ag5 ppm & Ag25 ppm & Ag50 ppm \\
\hline Thelephora terrestris & Thelephora terrestris (FJ809998.1) & MK660101 & 99 & $90.0 \pm 1.24$ & $82.5 \pm 1.17$ & $80.0 \pm 1.05$ & $87.5 \pm 1.12$ \\
\hline Paxillus involutus & Paxillus involutus (EU078725.1) & MK660102 & 98 & $22.5 \pm 0.87$ & $17.5 \pm 0.68$ & $25.5 \pm 0.48$ & $40.0 \pm 0.81$ \\
\hline Sphaerosporella brunnea & Sphaerosporella brunnea (KC008076.1) & MK660100 & 98 & $32.5 \pm 0.81$ & $52.5 \pm 0.95$ & $37.5 \pm 0.75$ & $32.5 \pm 0.74$ \\
\hline
\end{tabular}


of diverse heavy metals ( $\mathrm{Zn}, \mathrm{Pb}, \mathrm{Cd}$; Mleczko 2004). It is likely that $S$. brunnea is constitutively resistant to a wide range of stressors, possibly including AgNPs.

The proportion of P. involutus ECM was highest in the treatment with the highest dose of AgNPs, and lowest in the control treatment. Again, there was no strictly linear dose-response relationship, but it is clear that ECM formation by P. involutus was not impaired by the AgNP treatments applied. P. involutus is particularly resistant to metal stress (Denny and Wilkins 1987; Hintikka 1988; Bellion et al. 2007). Furthermore, P. involutus is a characteristic representative of ECM Boletales in forming complex rhizomorphs, which qualify this species as a long-distance explorer, in contrast to T. terrestris (medium distance explorer) and to S. brunnea (contact type) (Agerer 2001). The observation that ECM formation by $P$. involution was highest in the $50 \mathrm{ppm}$ AgNP treatment may be another indication that photosynthesis was not substantially inhibited by the treatments, since this species needs to maintain a complex and abundant rhizomorph system, which is probably costly in terms of carbohydrate requirements.

The shares accounted for by each of the three ECM species reported may also reflect competition between them, or else differentiated sensitivity to the action of AgNPs. Some studies (in in vitro cultures) do point to such a differentiated direct influence of NPs on (pathogenic and wood decay) fungi (AleksandrowiczTrzcińska et al. 2018). Our previous in vitro experiment for example found Amanita cirtina displaying a complete lack of sensitivity to the action of the nanoparticle, while Hebeloma crustuliniforme proved to be highly sensitive. AgNPs stimulate mycelial growth in Suillus luteus (unpublished data). On the one hand, these results indicate high selectivity of NP activity in relation to different species of EMC fungi, but on the other there can be no doubt that the reactions of fungi may be completely different under natural conditions.

$\mathrm{Ag}+$ and AgNPs are strong antibacterial and antifungal agents, but the potential to adapt to toxic concentrations of trace metals is widespread among populations of ECM fungi (Urban 2011). Former silver mining sites contaminated with diverse heavy metals were reported to be colonised by ECM fungi of the genera Cortinarius, Hebeloma, Inocybe, Laccaria, Tomentella, Tricholoma and Tuber, with Thelephoraceae (Tomentella) being dominant (Hrynkiewicz et al. 2008). Saprotrophic and ECM macrofungi were found to accumulate $\mathrm{Ag}$, in the case of Amanita sect. Vaginata and sect. Lepidella hyperaccumulation was observed (Borovicka et al. 2007, 2010). In Amanita strobiliformis intracellular Ag was demonstrated to be sequestered by multiple metallothioneins, i.e. cysteine-rich peptides involved in heavy metal tolerance of many eukaryotes (Osobová et al. 2011). Fungal species-specific accumulation of Ag and other heavy metals in ectomycorrhizae was suggested to protect host trees (Picea abies) from toxicity (Cejpková et al. 2016). These adaptations to $\mathrm{Ag}+$ exposition by diverse ECM fungi are in contrast to the nearly complete inhibition of ECM colonisation of Pinus muricata roots in experimental AgNP treatments (Sweet and Singleton 2015). The application of synthetic AgNPs to non-adapted ECM communities versus long-term exposure with naturally occurring silver species might explain the discrepancy of results.

The ECM fungi occurring spontaneously in the tree nursery are more or less stress-tolerant pioneer species not preadapted to silver stress. Shoots and leaves were the primary target of AgNP treatments, limited collateral exposure of soil and roots cannot be fully excluded, but was certainly orders of magnitude lower than exposure of foliage. ECM colonisation may have been influenced by (1) effects on plant condition (productivity, patterns of organic carbon allocation, stress responses, plant hormon status), (2) effects of silver (AgNPs od $\mathrm{Ag}+$ ) internally translocated to the roots or (3) leaching of AgNPs into the containers. Given the available evidence, we hypothesise that the probable impact of AgNPs on plant hormon balance explains best the aggregate effect on ECM development (see below). Shifts between the abundance of different ECM fungal species may be conditioned by the interaction of plant condition, direct AgNP effects on ECM fungal fitness and competition between ECM species, along with random effects. The complexity of these interactions may explain the non-linearity of the observed effects, particularly at the level of ECM fungal species.

Changes in root structure due to AgNPs include disrupted epidermal cells, highly vacuolated cortical cells (Yin et al. 2011: in Lolium multiflorum), shortened or completely reduced root hairs (Yin et al. 2011: in Lolium multiflorum; Vannini et al. 2013: in Eruca sativa), an increased production of lateral roots primordia (Vannini et al. 2014; in Triticum) and a reduction of the length of primary tap roots and of the development of lateral and fine roots at higher AgNP concentrations (Sweet and Singleton 2015; in Pinus muricata). Complete reduction of root hairs and increased branching are commonly observed in ECM symbiosis. This commonality led us to the hypothesis that AgNPs might induce physiological and structural changes in plant hosts which increase their susceptibility for ECM symbiosis. The development and branching of plant root systems is controlled by the crosstalk of plant hormones via signalling pathways (Smith and De Smet 2012). AgNPs share various effects on plant physiology with silver ions (Ag+; e.g. applied as $\mathrm{AgNO} 3$ ), while others appear to be specific to AgNPs (Yin et al. 2011; Kaveh et al. 2013; Vannini et al. 2013). Effects in polyamine-, ethyleneand calcium- mediated pathways are considered to be mediated by $\mathrm{Ag}+$ (Kumar et al. 2009). In addition to ethyleneregulated pathways, AgNPs were reported to interact with genes involved in auxin- and abscissic acid mediated signalling pathways (Kaveh et al. 2013; Syu et al. 2014). Many genes upregulated by AgNPs and Ag + were linked to oxidative stress and metal-induced stress, while downregulated genes were rather associated with response to pathogens and 
hormonal stimuli (Kaveh et al. 2013). The inhibitory effect of silver on ethylene action (Beyer Jr. 1976) was demonstrated to be predominantly mediated by ethylene receptor 1 (ETR1) in Arabidopsis thaliana (McDaniel and Binder 2012). Ethylene modulates numerous plant physiological processes, including root growth, root branching, root hair formation and interactions with mutualistic or parasitic symbionts (Kaveh et al. 2013; Syu et al. 2014). Ethylene-mediated defense is part of complex regulatory networks, involving inter alia jasmonic acid and salicylic acid. In general, ethylene is considered a negative regulator of mutualistic root symbioses, despite certain exceptions, e.g. Piriformospora indica (Khatabi and Schäfer 2012; Broekgaarden et al. 2015). Inhibition of ethylene-induced effects with $\geq 10 \mu \mathrm{M}$ silver thiosulfat had a neutral effect on ECM formation by Pisolithus tinctorius and a negative effect on Laccaria laccata (Rupp et al. 1989). It is important to note that silver thiosulfat was added to the liquid growth medium and may have directly impaired the growth of L. laccata. Plett et al. (2014) demonstrated that ethylene and jasmonic acid treatments reduced the development of the Hartig net in Laccaria bicolor/Populus ECM symbiosis, this effect was correlated to increased expression of certain transcription factors, including ERF1.

\section{Conclusions}

Stimulation of ECM formation by foliar-applied AgNPs, combined with neutral effects on seedlings growth parameters (Olchowik et al. 2017) and chlorophyll a fluorescence is a counterintuitive result, resistant to overly simplistic explanations based on photosynthesis efficiency and resulting organic carbon supply. Alternatively, interactions of AgNPs with plant hormones and developmental programs involved in host control of ECM symbiosis might cause variation in ECM colonisation at foliar AgNP exposition levels below acute toxicity. The design of this study on AgNPs, chlorophyll a fluorescence and ECM formation was originally motivated by the potential perspective of NP applications in forest nursery management and by the need to assess potential risks of AgNPs for biodiversity and forestry sustainability. In order to test our hypotheses linking AgNPs, plant hormone balance and ECM symbiotic relationships (Plett et al. 2014) transcriptomic and/or proteomic studies are required. To this end it may be advantageous to shift to a model host tree of ECM symbiosis, such as Populus.

Acknowledgments This work was supported by the Rector of Warsaw University of Life Sciences - SGGW - within the framework of the 50510-030400-L00374-99 research projects.

The editorial help of James R.A. Richards, $\mathrm{PhD}$, is also gratefully acknowledged. The second author gratefully acknowledges the Austrian Agency for International Mobility and Cooperation in Education, Science and Research (OeAD) for supporting his stay at the University of Vienna in 2015 and 2016.

\section{Compliance with ethical standards}

Conflict of interest The authors declare that they have no conflicts of interest.

Open Access This article is distributed under the terms of the Creative Commons Attribution 4.0 International License (http:// creativecommons.org/licenses/by/4.0/), which permits unrestricted use, distribution, and reproduction in any medium, provided you give appropriate credit to the original author(s) and the source, provide a link to the Creative Commons license, and indicate if changes were made.

\section{References}

Abd-Elsalam KA (2012) Nanoplatforms for plant pathogenic fungi management. Fungal Genom Biol 2:e107. https://doi.org/10.4172/2165$8056.1000 \mathrm{e} 107$

Agerer R (1987-2008) Colour atlas of ectomycorrhizae. 1st-15th del., Einhorn-Verlag, Schwäbisch Gmünd, Munich. Germany

Agerer R (2001) Exploration types of ectomycorrhizae. Mycorrhiza 11: $107-114$

Aleksandrowicz-Trzcińska M, Szaniawski A, Olchowik J, Drozdowski S (2018) Effects of copper and silver nanoparicles on growth in selected species of pathogenic and wood-decay fungi in vitro. For Chron 93(2): 109-116

Altschul SF, Madden TL, Schäffer AA, Zhang J, Zhang Z, Miller W, Lipman DJ (1997) Gapped BLAST and PSI-BLAST: a new generation of protein database search programs. Nucleic Acids Res 25: 3389-3402

Arruda SCC, Silva ALD, Galazzi RM, Azevedo RA, Arruda MAZ (2015) Nanoparticles applied to plant science: a review. Talanta 131:693-705. https://doi.org/10.1016/j.talanta.2014.08.050

Bellion M, Courbot M, Jacob C, Guinet F, Blaudez D, Chalot M (2007) Metal induction of a Paxillus involutus metallothionein and its heterologous expression in Hebeloma cylindrosporum. New Phytol 174:151-158. https://doi.org/10.1111/j.1469-8137.2007.01973.x

Beyer EM Jr (1976) A potent inhibitor of ethylene action in plants. Plant Physiol 58:268-271

Borovicka J, Randa Z, Jelínek E, Kotrba P, Dunn CE (2007) Hyperaccumulation of silver by Amanita strobiliformis and related species of the section Lepidella. Mycol Res 111:1339-1344. https:// doi.org/10.1016/j.mycres.2007.08.015

Borovicka J, Kotrba P, Gryndler M, Mihaljevic M, Randa Z, Rohovec J, Cajthaml T, Stijve T, Dunn CE (2010) Bioaccumulation of silver in ectomycorrhizal and saprobic macrofungi from pristine and polluted areas. Sci Total Environ 408:2733-2744. https://doi.org/10.1016/j. scitotenv.2010.02.031

Broekgaarden C, Caarls L, Vos IA, Pieterse CMJ, Van Wees SCM (2015) Ethylene: traffic controller on hormonal crossroads to defense. Plant Physiol 169:2371-2379. https://doi.org/10.1104/pp.15.01020

Cao J, Feng Y, He S, Lin X (2017) Silver nanoparticles deteriorate the mutual interaction between maize (Zea mays L.) and arbuscular mycorrhizal fungi: a soil microcosm study. Appl Soil Ecol 119: 307-316. https://doi.org/10.1016/j.apsoil.2017.04.011

Cejpková J, Gryndler M, Hršelová H, Kotrba P, Řanda Z, Synková I, Borovička J (2016) Bioaccumulation of heavy metals, metalloids, and chlorine in ectomycorrhizae from smelter-polluted area. Environ Pollut 218:176-185. https://doi.org/10.1016/j.envpol. 2016.08.009

Denny HJ, Wilkins DA (1987) Zinc tolerance in Betula spp. III. Variation in response to zinc among ectomycorrhizal associates. New Phytol 106:535-544 
Dubchak S, Ogar A, Mietelski JW, Turnau K (2010) Influence of silver and titanium nanoparticles on arbuscular mycorrhiza colonization and accumulation of radiocaesium in Helianthus annuus. Span J Agric Res 8:103-108. https://doi.org/10.5424/sjar/201008S1-1228

Falco WF, Queiroz AM, Fernandes J, Botero ER, Falcão EA, Guimarães FEG, M'Peko J-C, Oliveira SL, Colbeck I, Caires ARL (2015) Interaction between chlorophyll and silver nanoparticles - a close analysis of chlorophyll fluorescence quenching. J Photochem Photobiol A Chem 299:203-209. https://doi.org/10.1016/j. jphotochem.2014.12.001

Feng Y, Cui X, He S, Dong G, Chen M, Wang J, Lin X (2013) The role of metal nanoparticles in influencing arbuscular mycorrhizal fungi effects on plant growth. Environ Sci Technol 47:9496-9504. https:// doi.org/10.1021/es402109n

Gardes M, Bruns TD (1993) ITS primers with enhanced specificity for basidiomycetes - application to the identification of mycorrhizae and rusts. Mol Ecol 2:113-118

Hintikka V (1988) High aluminium tolerance among ectomycorrhizal fungi. Karstenia 28:41-44

Högberg P, Högberg MN, Göttlicher SG, Betson NR, Keel SG, Metcalfe DB, Campbell C, Schindlbacher A, Hurry V, Lundmark T, Linder S, Näsholm T (2008) High temporal resolution tracing of photosynthate carbon from the tree canopy to forest soil microorganisms. New Phytol 177:220-228. https://doi.org/10.1111/j.1469-8137. 2007.02238.x

Hrynkiewicz K, Haug I, Baum C (2008) Ectomycorrhizal community structure under willows at former ore mining sites. Eur J Soil Biol 44:37-44. https://doi.org/10.1016/j.ejsobi.2007.10.004

Iotti M, Zambonelli A (2006) A quick and precise technique for identifying ectomycorrhizas by PCR. Mycol Res 110:60-65. https://doi. org/10.1016/j.mycres.2005.09.010

Iwański M, Rudawska M, Leski T (2006) Mycorrhizal associations of nursery grown scots pine (Pinus sylvestris L.) seedlings in Poland. Ann For Sci 63:715-723. https://doi.org/10.1051/forest:2006052

Jiang HS, Yin LY, Ren NN, Zhao ST, Li Z, Zhi Y, Shao H, Li W, Gontero B (2017) Silver nanoparticles induced reactive oxygen species via photosynthetic energy transport imbalance in an aquatic plant. Nanotoxicology 11:157-167. https://doi.org/10.1080/17435390. 2017.1278802

Judy JD, Kirby JK, Creamer C, McLaughlin MJ, Fiebiger C, Wright C, Cavagnaro TR, Bertsch PM (2015) Effects of silver sulfide nanomaterials on mycorrhizal colonization of tomato plants and soil microbial communities in biosolid-amended soil. Environ Pollut 206:256-263. https://doi.org/10.1016/j.envpol.2015.07.002

Kaveh R, Li YS, Ranjbar S, Tehrani R, Brueck CL, Van Aken B (2013) Changes in Arabidopsis thaliana gene expression in response to silver nanoparticles and silver ions. Environ Sci Technol 47: 10637-10644. https://doi.org/10.1021/es402209w

Khatabi B, Schäfer P (2012) Ethylene in mutualistic symbioses. Plant Signal Behav 7:1634-1638. https://doi.org/10.4161/psb.22471

Klaine S, Alvarez PJJ, Batley GE, Fernandes TF, Handy RD, Lyon DY, Mahendra S, McLaughlin MJ, Lead JR (2008) Nanomaterials in the environment: behavior, fate, bioavailability, and effects. Environ Toxicol Chem 27(9):1825-1851. https://doi.org/10.1897/08-090.1

Kõljalg U, Nilsson RH, Abarenkov K, Tedersoo L, Taylor AFS, Bahram M, Bates ST, Bruns TD, Bengtsson-Palme J, Callaghan TM, Douglas B, Drenkhan T, Eberhardt U, Dueñas M, Grebenc T, Griffith GW, Hartmann M, Kirk PM, Kohout P, Larsson E, Lindahl BD, Lücking R, Martín MP, Matheny PB, Nguyen NH, Niskanen T, Oja J, Peay KG, Peintner U, Peterson M, Põldmaa K, Saag L, Saar I, Schüßler A, Scott JA, Senés C, Smith ME, Suija A, Taylor DL, Telleria MT, Weiß M, Larsson KH (2013) Towards a unified paradigm for sequence-based identification of. Fungi Mol Ecol 22:5271-5277. https://doi.org/10.1111/mec.12481

Kumar V, Parvatam G, Ravishankar GA (2009) AgNO3: a potential regulator of ethylene activity and plant growth modulator. Electron J
Biotechnol 12:8-9. https://doi.org/10.4067/S071734582009000200008

Last FT, Dighton J, Mason PA (1987) Successions of sheathing mycorrhizal fungi. Trends Ecol Evol 2:157-161

Leski T, Pietras M, Rudawska M (2010) Ectomycorrhizal fungal communities of pedunculate and sessile oak seedlings from bare-root forest nurseries. Mycorrhiza 20:179-190. https://doi.org/10.1007/s00572009-0278-6

Ma X, Geiser-Lee J, Deng Y, Kolmakov A (2010) Interactions between engineered nanoparticles (ENPs) and plants: phytotoxicity, uptake and accumulation. Sci Total Environ 408(16):3053-3061. https:// doi.org/10.1016/j.scitotenv.2010.03.031

Maxwell K, Johnson NG (2000) Chlorophyll fluorescence - a practical guide. J Exp Bot 51:659-666

McDaniel B, Binder BM (2012) Ethylene Receptor1 (ETR1) is sufficient and has the predominant role in mediating inhibition of ethylene responses by silver in Arabidopsis thaliana. J Biol Chem 287: 26094-26103. https://doi.org/10.1074/jbc.M112.383034

Menkis A, Vasiliauskas R, Taylor AF, Stenlid J, Finlay R (2005) Fungal communities in mycorrhizal roots of conifer seedlings in forest nurseries under different cultivation systems, assessed by morphotyping, direct sequencing and mycelial isolation. Mycorrhiza 16:33-41

Mleczko P (2004) Mycorrhizal and saprobic macrofungi of two zinc wastes in southern Poland. Acta Botanica Cracoviensa - Series Botanica 46:25-38

Mukhopadhyay SS (2014) Nanotechnology in agriculture: prospects and constraints nanotechnology. Nanotechnol Sci Appl 7:63-71. https:// doi.org/10.2147/NSA.S39409

Nel A, Xia T, Mädler L, Li N (2006) Toxic potential of materials at the nanolevel. Science 311:622-627. https://doi.org/10.1126/science. 1114397

Olchowik J, Bzdyk R, Studnicki M, Bederska-Błaszczyk M, Urban A, Aleksandrowicz-Trzcińska M (2017) The effects of silver and copper nanoparticles on the condition of English oak (Quercus robur L.) seedlings in a container nursery experiment. Forests 8:310. https:// doi.org/10.3390/f8090310

Osobová M1, Urban V, Jedelský PL, Borovička J, Gryndler M, Ruml T, Kotrba P (2011) Three metallothionein isoforms and sequestration of intracellular silver in the hyperaccumulator Amanita strobiliformis. New Phytol 190:916-926. https://doi.org/10.1111/j. 1469-8137.2010.03634.x

Percival GC (2005) The use of chlorophyll fluorescence to identify chemical and environmental stress in leaf tissue of three oak (Quercus) species. J Arboric 31:215-221

Pietras M, Rudawska M, Leski T, Karliński L (2013) Diversity of ectomycorrhizal fungus assemblages on nursery grown European beech seedlings. Ann For Sci 70:115-121. https://doi.org/10.1007/ s13595-012-0243-y

Plett JM, Khachane A, Ouassou M, Sundberg B, Kohler A, Martin F (2014) Ethylene and jasmonic acid act as negative modulators during mutualistic symbiosis between Laccaria bicolor and Populus roots. New Phytol 202:270-286. https://doi.org/10.1111/nph.12655

Razzaq A, Ammara R, Jhanzab HM, Mahmood T, Hafeez A, Hussain S (2016) A novel nanomaterial to enhance growth and yield of wheat. J Nanosci Tech 2(1):55-58

Rizwan M, Ali S, Qayyum MF, Ok YS, Adrees M, Ibrahim M, Zia-urRehman M, Farid M, Abbas F (2017) Effect of metal and metal oxide nanoparticles on growth and physiology of globally important food crops: a critical review. J Hazard Mater 322:2-16. https://doi. org/10.1016/j.jhazmat2016.05.061

Rudawska M, Leski T, Trocha LK, Gornowicz R (2006) Ectomycorrhizal status of Norway spruce seedlings from bare-root forest nurseries. For Ecol Manag 236:375-384. https://doi.org/10.1016/j.foreco. 2006.09.066

Ruffini Castiglione M, Cremoni R (2009) Nanoparticles and higher plants. Caryologia 62(2):161-165 
Rupp LA, Mudge KW, Negm FB (1989) Involvement of ethylene in ectomycorrhiza formation and dichotomous branching of roots of mugo pine seedlings. Can J Bot 67:477-482. https://doi.org/10. 1139/b89-067

Sánchez S, Gómez E, Martín M, De Miguel AM, Urban A, Barriuso J (2014) Experiments on the life cycle and factors affecting reproduction of Sphaerosporella brunnea provide evidence for rapid asexual propagation by conidiospores and for homothallism in an ectomycorrhizal competitor of cultivated truffle species. Fungal Ecol 8:59-65

Sharma P, Bhatt D, Zaidi MG, Saradhi PP, Khanna PK, Arora S (2012) Silver nanoparticle- mediated enhancement in growth and antioxidant status of Brassica juncea. Appl Biochem Biotechnol 167: 2225-2233. https://doi.org/10.1007/s12010-012-9759-8

Smith S, De Smet I (2012) Root system architecture: insights from Arabidopsis and cereal crops. Philos Trans R Soc Lond Ser B Biol Sci 367:1441-1452. https://doi.org/10.1098/rstb.2011.0234

Smith SE, Read DJ (2008) Mycorrhizal Symbiosis. Academic Press, Cambridge, Great Britain. ISBN: 978-0-12-370526-6

Sweet MJ, Singleton I (2015) Soil contamination with silver nanoparticles reduces Bishop pine growth and ectomycorrhizal diversity on pine roots. J Nanopart Res 17:448. https://doi.org/10.1007/s11051015-3246-4

Syu Y-Y, Hung J-H, Chen J-C, Chuang H-W (2014) Impacts of size and shape of silver nanoparticles on Arabidopsis plant growth and gene expression. Plant Physiol Biochem 83:57-64. https://doi.org/10. 1016/j.plaphy.2014.07.010

Urban A (2011) Metal elements and the diversity and function of ectomycorrhizal communities. In: diversity and biotechnology of Ectomycorrhiza. Mahendra rai and Ajit Varma (Eds). SOILBIOL 25:231-254

van der Heijden MGA, Martin FM, Selosse M-A, Sanders IR (2015) Mycorrhizal ecology and evolution: the past, the present, and the future. New Phytol 205:1406-1423. https://doi.org/10.1111/nph. 13288
Vannini C, Domingo G, Onelli E, Prinsi B, Marsoni M, Espen L, Bracale M (2013) Morphological and proteomic responses of Eruca sativa exposed to silver nanoparticles or silver nitrate. PLoS One 8:e68752. https://doi.org/10.1371/journal.pone.0068752

Vannini C, Domingo G, Onelli E, De Mattia F, Bruni I, Marsoni M, Bracale M (2014) Phytotoxic and genotoxic effects of silver nanoparticles exposure on germinating wheat seedlings. J Plant Physiol 171:1142-1148. https://doi.org/10.1016/j.jplph.2014.05.002

Villeneuve N, Le Tacon F, Bouchard D (1991) Survival of inoculated Laccaria bicolor in competition with native ectomycorrhizal fungi and effects on the growth of outplanted Douglas-fir seedlings. Plant Soil 135:95-108

White TJ, Bruns T, Lee S, Taylor J (1990) Amplification and direct sequencing of fungal ribosomal RNA genes for phylogenetics. In: In: "PCR Protocols: a Guide to Methods and Applications" (Innis MA, Gelfand DH, Sninsky JJ, White TJ eds). Academic Press, New York, USA, pp 315-322

Yin L, Cheng Y, Espinasse B, Colman BP, Auffan M, Wiesner M, Rose J, Liu J, Bernhardt ES (2011) More than the ions: the effects of silver nanoparticles on Lolium multiflorum. Environ Sci Technol 45:2360 2367. https://doi.org/10.1021/es103995x

Zheng L, Su M, Wu X, Liu C, Qu C, Chen L, Huang H, Liu X, Hong F (2008) Antioxidant stress is promoted by nano-anatase in spinach chloroplasts under UV-B radiation. Biol Trace Elem Res 121:69-79. https://doi.org/10.1007/s12011-007-8028-0

Publisher's note Springer Nature remains neutral with regard to jurisdictional claims in published maps and institutional affiliations. 